artelogie

\section{Artelogie}

Recherche sur les arts, le patrimoine et la littérature de l'Amérique latine

$15 \mid 2020$

Latin American networks: Synchronicities, Contacts and Divergences.

\title{
Far from Good Design: Social Responsibility and Waldemar Cordeiro's Early Theory of Form
}

\section{Adele Nelson}

\section{(2) OpenEdition \\ Journals}

Electronic version

URL: http://journals.openedition.org/artelogie/4374

DOI: 10.4000 /artelogie.4374

ISSN: $2115-6395$

Publisher

Association ESCAL

\section{Electronic reference}

Adele Nelson, «Far from Good Design: Social Responsibility and Waldemar Cordeiro's Early Theory of Form », Artelogie [Online], 15 | 2020, Online since 08 April 2020, connection on 10 December 2020.

URL : http://journals.openedition.org/artelogie/4374 ; DOI : https://doi.org/10.4000/artelogie.4374

This text was automatically generated on 10 December 2020.

Association ESCAL 


\section{Far from Good Design: Social Responsibility and Waldemar Cordeiro's Early Theory of Form}

\section{Adele Nelson}

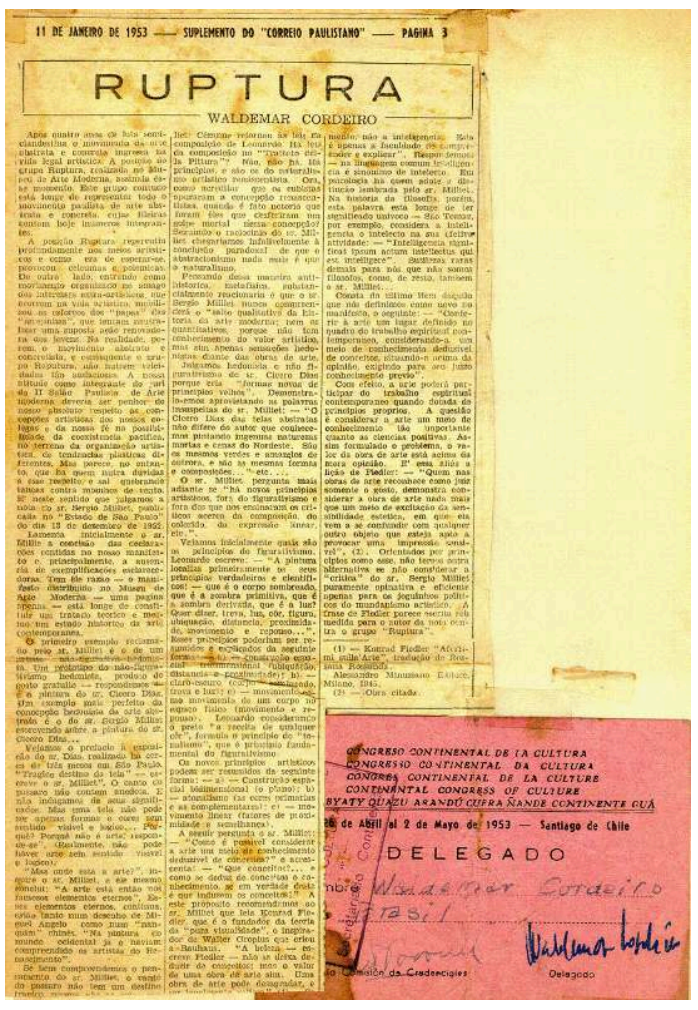

Figure 1. Waldemar Cordeiro. "Ruptura." Correio paulistano (São Paulo), January 11, 1953. Visible in lower right: Waldemar Cordeiro's delegate card for the Continental Congress for Culture, Santiago, 1953. Cordeiro Family Archive.

1 Let's begin with an incident of the archive: the juxtaposition of a clipping of an article by Waldemar Cordeiro with his signed, stamped, and coffee stained delegate card for 
the Continental Congress for Culture organized by Pablo Neruda in Santiago, Chile (figure 1). ${ }^{1}$ Both date to first half of 1953: Cordeiro's article "Ruptura" was published on January 11, 1953 in the high-brow Sunday supplement Pensamento e Arte of the oldest daily newspaper in São Paulo, Correio paulistano. From April 26-May 2, 1953, along with architect João Vilanova Artigas and poet Décio Pignatari and financed by the Partido Communista Brasileiro (Brazilian Communist Party, PCB), Cordeiro attended the Congress, which historian Patrick Iber has described as both one of the most important Latin American gathering of the Soviet-backed Peace Movement and the "a last gasp of cultural Stalinism." ${ }^{2}$ The only combining of documents I am aware of in Cordeiro's papers, the haphazard assemblage of evidence of political work with a product of intellectual labor - adhered to a backing page with scotch tape, the clipping lopping off several paragraphs and overlaid on the red-now-pink card beneath - may be accidental. The confluence nonetheless provokes a series of questions: what was the relationship between Cordeiro's Communism and his artistic theory and practice - for him and as perceived by his contemporaries? Via what interpretative paths did Cordeiro connect his theory of abstraction with the social realm? Despite Cordeiro wellearned reputation as a polemical defender of abstract art, did he seek to articulate an understanding of abstraction that would be intelligible and perhaps even attractive to his political allies and pro-realist aesthetic rivals?

2 Cordeiro, Italian-born, a national of both Brazil and Italy, attended a prestigious secondary school in Rome and studied at the Accademia di Belle Arti di Roma as a teenager before emigrated to São Paulo in 1946. By the late 1940s, he was recognized as a leading young abstract artist and held a megaphone as a regular contributor to the daily, wide-circulation newspaper Folha da manhã. Cordeiro's political activities were ad hoc and focused on the realm of culture. ${ }^{3}$ Specifically, he was at the forefront of putting the feet of the new private art institutions, the Museu de Arte Moderna de São Paulo (MAM-SP) and the São Paulo Bienal principal among them, to the fire despite being a beneficiary of their attention to his work. At times, his art criticism overflowed with political discourses, revealing a thinker trying to reconcile Marxism and formalist art theory in order to assert that abstraction was connected to day-to-day, material reality. At others he foregrounded concerns about aesthetic theory and art history. By drilling down on Cordeiro's theory of form in little studied and well-known texts of the late 1940s-early 1950s and examining his dialogues and disagreements with Brazilian critics Mário Pedrosa and Sérgio Milliet, my paper seeks to revise the overly black-and-white conflation of Cordeiro's thinking with that of Max Bill and trace some of the interpretative paths Cordeiro traversed to connect his theory of abstraction with reality.

\section{Cordeiro's Pre-Ruptura Conception of Form}

3 The noun forma was on the tips of the tongues of abstraction-inclined artists and critics postwar in Brazil's cosmopolitan centers. Pedrosa and his 1949 thesis were key sources for young artists' concentrated attention to form and visual perception. ${ }^{4}$ The theorization of form in mid-century artistic circles in Rio and São Paulo nevertheless was not limited to Pedrosa nor to interpretations of Gestalt theory. Cordeiro also emphasized the notion of form in his art writing, including in his first programmatic texts dedicated to abstraction from 1949: "Abstracionismo" (Abstraction) and "Ainda o 
abstracionismo" (Abstraction Continued or Still More Abstraction). ${ }^{5}$ There Cordeiro called for an abstract art focused on formal relationships. He criticized figuration and the notion of expressing emotions in art. He argued that "only by objectivizing and depersonalizing form can one make it a matter of reflection, making the work comprehensible." Cordeiro's subsequent writing, however, did not banish emotion from his conception of abstraction, and the vision of form he articulated hewed to a more wandering path between representation and abstraction, expression and objectivity than his 1949 rhetoric might suggest.

4 Cordeiro's early theory of abstraction writ large was not steeped in or explicitly framed by Gestalt theory. While he acknowledged Bill's interest in Gestalt, as well as topology and relativity - and these are undoubtedly principal subjects among the new scientific knowledge that he argued oriented Ruptura practice in the 1952 manifesto - Gestalt was not a sustained subject of inquiry in his early writing. ${ }^{7}$ His notebooks and copious reviews of the late 1940 s and early 1950s are instead historiographic in profile. Cordeiro sought to position the new art of young Brazilian artists in relationship to particular trajectories within European modernism and to steep himself in modern art histories, as exemplified by his transcription and translation of Michel Seuphor's 1949 Abstract Art: Its Origins, Its First Masters. ${ }^{8}$ Components of his early writing are also characterized by a hit-you-over-the-head integration of Marxist terminology. In "Abstracionismo," Cordeiro repeatedly called for a dialectical understanding of new art, arguing that abstraction represents a "resolute qualitative leap" within the struggle of opposing artistic trends and, as scholar Vivaldo Medeiros identified, quoting an extended explanation of dialectics from Stalin's 1938 text Dialectical and Historical Materialism. ${ }^{9}$ In an unpublished text from c. 1948-49, he articulated how abstraction was, to his mind, vitally "connected to the material life of our society, never disconnected from real life." 10

5 Following the late 1940s polemical salvos and until the Ruptura manifesto in 1952, Cordeiro soft-pedaled the discussion of dialectics in favor of his advocacy for artist-run organizations and for artists' input into decision-making at the new modern art museums, all privately run institutions, on one hand, and detailed description and analysis of abstract art and artists, on the other. Put differently, Cordeiro adopted a twofold strategy: he articulated an institutional argument, arguing for the crucial role of artist-run organizations - the Salão paulista de arte moderna (established 1951) among them - in the ecosystem of a bevy of new private art entities and espousing the responsibility of the state and art institutions to support artists. ${ }^{11}$ Concurrently, through reviews of exhibitions by emerging artists and profiles of artists, he modeled a serious analysis of abstraction, removed from the realm of "propaganda" and "returned to aesthetics," and shined attention on the lives of artists, whom he described as hard-working, self-made contributors to society. ${ }^{12}$ In the wake of his and others' sustained advocacy for artists to be incorporated into the decision making at the São Paulo Bienal and Brazilian representations to the Venice Biennale and in anticipation of the IV Centenário celebration in 1954, Cordeiro viewed new modern art institutions, and the generous public financial support for the Bienal in particular, with skepticism. They were making possible a flourishing of the national art scene, of a scale comparable to the Italian Renaissance he suggested at one point, but he also viewed them as adversaries, describing the Bienal was "an authoritarian, patron organization," uninterested in a sustained livelihood for artists and attempting to dictate the direction 
of Brazilian art. ${ }^{13} \mathrm{~A}$ through-line in his art writing of these years was an interest in the lives of artists and the aspiration, in between the private and artist-run art organizations, for "a return of the artist to a collective life." ${ }^{14}$

6 Cordeiro's definition of form, while distinct from Pedrosa's affective form and radically inclusive conception of modernism, did not cleave abstraction from lived experience, as can be seen in their shared admiration for Geraldo de Barros. Pedrosa described Barros as "the most fertile researcher of his generation" and was in active dialogue with Barros in the early 1950s. ${ }^{15}$ Cordeiro and Barros had been friends since the late 1940s, and Cordeiro praised Barros's seriousness and talent to others in both correspondence and reviews. ${ }^{16}$ In his review of Barros's 1951 exhibition at the Museu de Arte de São Paulo (Museum of Art of São Paulo, MASP), Cordeiro declared that Barros represented a definitive break in Brazilian art, closing one chapter and opening another. ${ }^{17}$ Barros's experimentation with media and "denaturalization" of mimesis created what Cordeiro described as "new and utterly inventive relations" and formal interplays. ${ }^{18}$ While Cordeiro read the artist's experimental photographs as a rejection of straight realism, he also evidenced a more inclusive criteria for vanguard abstraction than his first texts suggested, lauding Barros's othering of representation. Cordeiro wrote, "Geraldo saw new horizons and turned his attention to those forms that spoke most revealingly of human potential." 19

7 Pedrosa and Cordeiro's respective assessments of Almir Mavignier's 1951 solo exhibition held at MAM-SP reveal crucial differences in their theories of form. Cordeiro was baffled by such an erudite thinker as Pedrosa advocating for Mavignier, noting that he did not think Mavignier's production warranted a solo exhibition at MAM-SP. ${ }^{20}$ In the texts Pedrosa authored to accompany the exhibition, he describes the young artist's works as "pure formal research," and argued that current thinking on visual perception, especially the relationships of color and form to psychology, provide an important theoretical tool kit for experimental artists like Mavignier. ${ }^{21}$ Cordeiro, by contrast, asserted that Mavignier's paintings were poorly executed post-Cubist exercises polluted by self-expression and therefore to his mind unintelligible and muddled. He did not engage Pedrosa's view of the paintings as studies of perception. ${ }^{22}$ Cordeiro's acerbic dismissal of Mavignier rested in part on a critique of his sources in European modernism, namely the concentrated study of tonal variation of Pierre Bonnard and Giorgio Morandi and the biomorphism of Joan Miró, references Cordeiro considered passé. He also did not accept the distinction Pedrosa asserted between affective and expressive and read the works as a continuation of Expressionism, an orientation Cordeiro and other abstract artists saw themselves as having shaken off by the early 1950s. The title of Cordeiro's review of the exhibition, "Forms That Are Not Forms," speaks not only to the function of the term "form" as a watchword in emerging abstractionist circles, but also to the divergent thinking underway among allied artists and thinkers. Cordeiro accused Mavignier of disingenuously masking his retrograde Cubist and Expressionist practice with theoretical terminology, a condition he argued was widespread in the ascent of wishy-washy "abstractionism" in Brazil. His insistence that the notion of form be tethered to intelligibility and legibility echoed Cordeiro's earlier critique of Expressionism as "forms that cannot be known." ${ }^{23}$

8 In a subsequent text, later in 1951, Cordeiro most fully defined his pre-Ruptura conception of form, employing the neologism forma-idéia to define the goal of 
nonobjective art. Specifically, when writing about a painting by Luis Sacilotto, he wrote:

This is an abstract picture. The artist did not draw his impressions directly from the actual scene; rather, he drew the content from his own life experience. His impressions developed within the "neo-plasticist" artistic conception, which is expressed by the motion of colored planes that act jointly or in opposition. He conducted a thoughtful research and, by developing the geometric theme, achieved the 'forma-idéia', which is the synthesis of scientific concepts and justified intuitions. ${ }^{24}$

9 The scientific concepts at stake for Cordeiro were the color and compositional theories of artists like Mondrian synthesized with what he vaguely described as "justified intuitions." ${ }^{25}$ The lived experience, and intuition, Cordeiro considered paramount - as detailed in a series of rosy profiles on Sacilotto, Alfredo Volpi, and other artists - was that of the working-class and emerging middle-class skilled laborers and artisans of the expanding metropolis. ${ }^{26}$ Cordeiro singles out Sacilotto's training and employment as a letterer, hand-painting the minute and precise letters and numbers on the tabulating cards for the Hollerith system, the progenitor of the IBM punch card. He argues that Sacilotto's mastery of this system, and that of architectural drafting, allowed the artist to create "analogies and relations with things and peoples." ${ }^{27}$ Rather than Expressionism or realism, Sacilotto was crafting a nonobjective abstraction that drew, non-mimetically, on the urban modern experience and technical systems creating "an easily read art" accessible to all audiences. ${ }^{28}$ Forma-idéia denotes the ideal achieved when an artist activates nonobjective abstraction, grounded in color and compositional theory of the European constructive avant-garde, with lived systems of urban modernity.

10 Cordeiro aligned his theory of forma-idéia with Bill's anti-illusionism, mentioning Concrete art and its suitability to the contemporary moment at the conclusion of the text. But the theory of form put forward by Cordeiro differed from Bill's in both its terms and in the place assigned to the social realm. Bill wrote extensively about the notion of form, and for Cordeiro, who was not in Pedrosa's immediate circle, Bill along with the Italian artistic group Forma were among the sources and foils for his own theorization of form..$^{29}$ In 1951 Bill's first text to be translated into Portuguese, "Beauty from Function and as Function," originally written in 1948, appeared in Habitat: Revista das artes no Brasil to accompany his exhibition at MASP. ${ }^{30}$ In the text, amid his call for educational reforms oriented toward training industrial designers, Bill asserts a reorientation of our understanding of the role of beauty in artistic and design processes. He acknowledges the responsibility of the designer to "make useful, ethical products," but argues that it is beauty, which he describes the "more universal need to give things form," that motivates all artistic and design processes, not "social responsibility." ${ }^{11}$ Bill's 1952 publication Form: A Balance Sheet of Mid-Twentieth Century Trends in Design is a compendium of examples of mid-century design and art modeled on the 1949 traveling exhibition Die Gute Form (Good Design). The book elucidates Bill's interests, which were formalist, evolutionary, and qualitative. Bill defined form "as an attempt to make inert matter embody perfect suitability for a given purpose in such a way that the fusion achieves beauty." ${ }^{32}$ Cordeiro grappled with Bill's privileging of beauty - he at one point characterizes abstract and Concrete art as "beauty invented by man for man. ${ }^{{ }^{33}}$ But his objection to idealism ultimately prevented him from investing 
in beauty as a category, and his notion of forma-idéia, in contrast, was interested in the enmeshment of creative processes in economic, social, and quotidian experience.

\section{Ruptura Conception of Form}

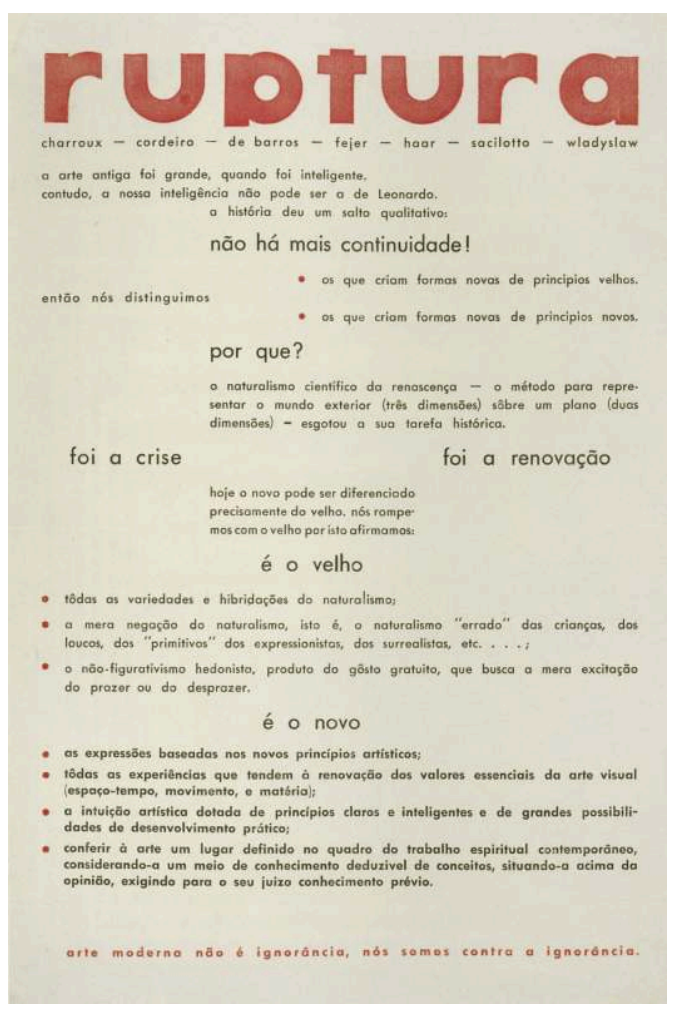

Figure 2: Manifesto Ruptura, 1952. Offset lithograph, $13 \times 85 / 8$ in. $(33 \times 22$ cm).

11 At the opening of the Grupo Ruptura exhibition in December 1952, the artists distributed a collectively signed manifesto (figure 2). The scholarly consensus is that Cordeiro was the document's primary author; he was an established polemicist and the sole member of the group who also worked as an art critic and regularly published texts. While I agree it is likely that Cordeiro had the largest role in the manifesto's authorship, recently uncovered notes in the archives of Barros as well as the annotated draft of manifesto suggest that dialogue among at least some of the group's members informed and surrounded the manifesto..$^{34}$ The notes in the Barros archive share content with the manifesto, most notably the enumeration of the same fundamental values of visual art - space-time, movement, and matter - and attention to the distinction from Renaissance naturalism. The notes, however, do not temper the artists' view of Concrete art as the leading edge of contemporary art (figure 3). In contrast, the exhibition invitation describes Grupo Ruptura as an "abstractionist group," and the manifesto calls for a future national exhibition of abstract and Concrete art. Based the notes, we can speculate that the collective discussion in the group was more historiographic and pedagogical in orientation than political and through diagrams, lists, and what may be doodles or heuristics - sought to articulate a model of historical change, the conceptual differences between Renaissance naturalism, Cubism, and Concrete art, and the relationship between theory and practice. The removal of a line riffing on the Communist Manifesto in the annotated 
draft of manifesto - "from the ruins emerged a new conception of art" - suggests that other members of Ruptura decided to omit an explicit allusion to Marxism (figure 4). ${ }^{35}$

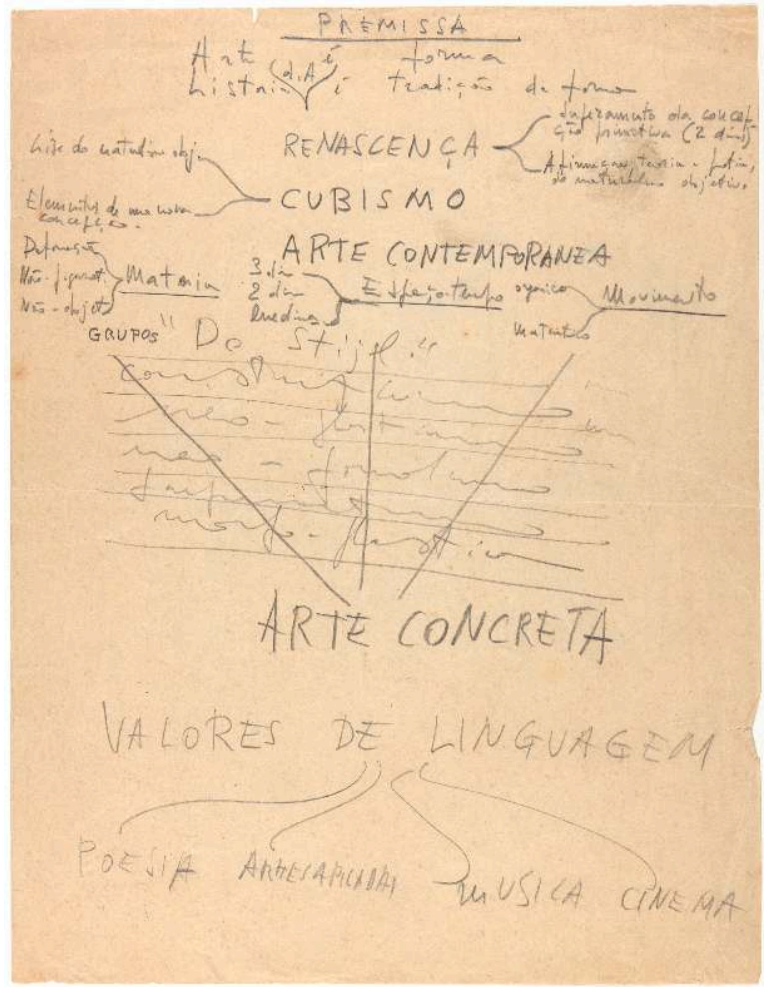

Figure 3: Notes by Grupo Ruptura members, c. 1952. Geraldo de Barros Archive.

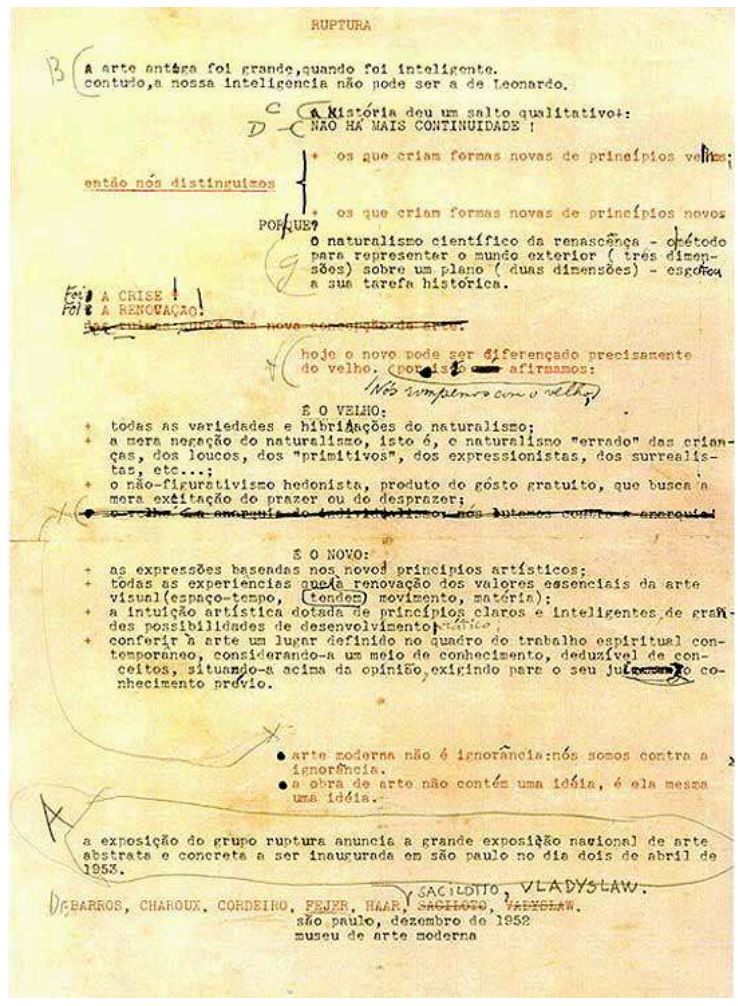

Figure 4: Draft of the Manifesto Ruptura, 1952. Pedro Corrêa do Lago Collection, São Paulo. Reproduced in João Bandeira's Arte concreta paulista: Documentos (2002). 
In the Ruptura manifesto and subsequent texts and talks, Cordeiro resurfaced his dialectical understanding of the history of art and expanded his aesthetic theory, drawing on the thinking of German aesthetic theorist Konrad Fielder. The title the group adopted, Rupture, and a series of statements in the manifesto - "there is no more continuity! / why? / it was a crisis / it was a renovation" singled out graphically by their justification and larger, bolded font - made no bones about the artists' non-linear, non-progressive, disruptive understanding of the history. ${ }^{36}$ The disagreement about whether the history of art represented a continuous linear progression or, as the Ruptura manifesto stated, was defined by qualitative leaps and ruptures was a longstanding one between Cordeiro and Sérgio Milliet, an esteemed public intellectual and an art and literary critic for the most prestigious newspaper in São Paulo almost thirty years senior to Cordeiro. Beginning in 1950, Cordeiro had targeted Milliet, describing his art criticism as idealist, metaphysical, and prone to defaulting to notions like allegories that Cordeiro considered inappropriate to understanding contemporary art. ${ }^{37}$ In December 1952 in a review of the Grupo Ruptura exhibition while it remained on view, Milliet finally took Cordeiro's bait and, in a departure from the typically deferential tone of his art writing, pilloried the manifesto for its claim that abstraction represented a break from Renaissance illusionism. ${ }^{38}$ Cordeiro's response appeared a month later, after the holidays, and was calculated for maximum effect to amplify the status of abstraction, the Ruptura group, and Cordeiro, and to most effectively counteract Milliet and what Cordeiro perceived as the old guard: in the lengthy article Cordeiro repeatedly footnoted references to Fielder, a little discussed nineteenth century thinker, and he placed the text not in his middle-market home newspaper, Folha da manhã, but in the high-brow Correio paulistano Sunday supplement, where it appeared with considerations of continental philosophy and European, U.S., and domestic art and culture. $^{39}$

The January 1953 article expanded Cordeiro's critique of Milliet's “anti-historic, metaphysical, substantially reactionary" understanding of modern history to differentiate their respective theories of visual art. ${ }^{40}$ In so doing, Cordeiro reveals that Fiedler's thinking underpinned several pillars of "the new" enumerated in the Ruptura manifesto, namely that art is derived from principles and art is a means of knowledge deduced from concepts and above mere opinion, as well as the larger ambition "to bestow on art a definite place within the scope of contemporary spiritual work." ${ }^{41}$ Moreover, the statement on the verso of the manifesto, "The work of art does not contain an idea, it is itself an idea," is an unattributed quotation from Fielder..$^{42}$ In his 1953 article, Cordeiro quotes passages from a 1945 translation of the Aphorisms section of Fiedler's posthumously published collected writings dismissing both beauty and taste as appropriate criteria with which to understand art, including the passage: "Beauty is not deducible from concepts, but the value of the work of art is. The work of art can displease and be equally valuable." ${ }^{\prime 3}$ As in his earlier articulation of forma-idéia, Cordeiro insists that the contribution of abstract art resides not in its appeal to aesthetic pleasure, but in its derivation from rigorous and timely concepts. But if, in Cordeiro's pre-Ruptura theory of abstraction, the social entered via artists like Sacilotto's or Barros's non-mimetic engagement with the current technologies and modern, urban experience, in the Ruptura manifesto and its defense by Cordeiro the social realm comes via claiming the seismic historical and spiritual import of art conceived as a form of knowledge. 
In late 1953 and early 1954, Cordeiro gave several talks on Concrete art. ${ }^{44}$ The context was a six-week course on modern and contemporary art for the Curso Internacional de Férias-Pró Arte (Pró Arte International Holiday Course) that he taught between Teresópolis and São Paulo from early January-late February 1954, including holding some of the class meetings in the galleries of the second Bienal. ${ }^{45}$ Fiedler remained a mainstay in Cordeiro's proposals in his remarks, but Cordeiro also directly responded to the conception of modernism Pedrosa put forward in his writing of the 1940s and 1950s and in his organization of the European special exhibitions at the second Bienal. Pedrosa's Panorama of Modern Painting (1952) adopted Heinrich Wölfflin's notion of enduring stylistic binaries and proposed a teleological account of modern art in which Impressionism and Cubism beget a succession of artistic movements that can be distilled into two opposing trajectories, which Pedrosa describes as expressionist and constructive. ${ }^{46}$ (Though, as I discuss elsewhere, Pedrosa's interest was in the outliers to these trajectories, commitments that informed his curatorial efforts to bring a Paul Klee special exhibition to the Bienal. ${ }^{47}$ ) Cordeiro articulates a broadly similar account of modern art history, although he tweaked Pedrosa's terminology and emphasized the dialectical nature of art history. Rather than expressive and constructive tendencies, he proposes that the two "fundamental opposing tendencies" in modern art are the art of expression, on one hand, and the art of creation or art as a form of knowledge, on the other ${ }^{48} \mathrm{He}$ pointed to works and exhibitions at the second Bienal to illustrate the differing approaches, including specific paintings by James Ensor, Edvard Munch, and others and comparing Cubism and Futurism as proposals. His interpretation of these opposing trajectories is struck through with Marxist thought. He asserted that expressive art limited itself to quantitative changes and remain in the "feudal phase." "The art of creation," on the other hand, understood art as a form of knowledge and therefore allows "qualitative leaps." ${ }^{49}$

Bill was entirely absent from these discussions, though Cordeiro's continued dismissal of beauty and his critique of the most prominent promoter of Concretism in the Americas, Argentine critic Jorge Romero Brest, whom he described as an idealist critic employing the outmoded tools of aesthetics, indicate that Cordeiro sought to supplant both as the primary spokesperson for Concrete art. Instead Cordeiro privileged the European historical avant-garde of the teens and twenties, citing Theo Van Doesburg as the term's originator, and integrating an analysis of Suprematism, Neo-plasticism, and Constructivism with a discussion of philosophy. Fiedler, employed previously as a bludgeon against Milliet and a signifier of the greater sophistication of Cordeiro's theory of art, was identified in these lectures as the founder of the concept of pure visibility and functioned as the model of a non-idealist, non-formalist, materialist conception of art. The German thinker insisted that art is not a secondary form of cognition, but an independent and unique form of knowledge, grounded in its own methods, equal to science and philosophy, and with a singular purchase on reality. For Cordeiro, the privileging of visibility as an ultimate manifestation of reality was revolutionary. Only nonobjective abstract works that negated both naturalism and Expressionism, i.e. Concrete art, could forge a transformative, radical form of communication with viewers. Rephrasing Fielder's statement that art does not contain an idea, but is an idea in and of itself, Cordeiro stated, "Art does not express a reality, it is a reality in itself." ${ }^{50}$ As he mapped in a diagram among his scripts for his late 1953 and early 1954 talks, Concrete geometry is understood not only as image, phenomenon, and perception - the lens we tend to apply to Brazilian Concretism - but also as a 
relation which is dialectical and real, a direct construction (figure 5).${ }^{51} \mathrm{He}$ also placed forma, as a noun, not adjective, among the terms explicating the type of relation Concrete art achieves. As in his earlier formulation of forma-idéia, he viewed form as tied to the social realm.

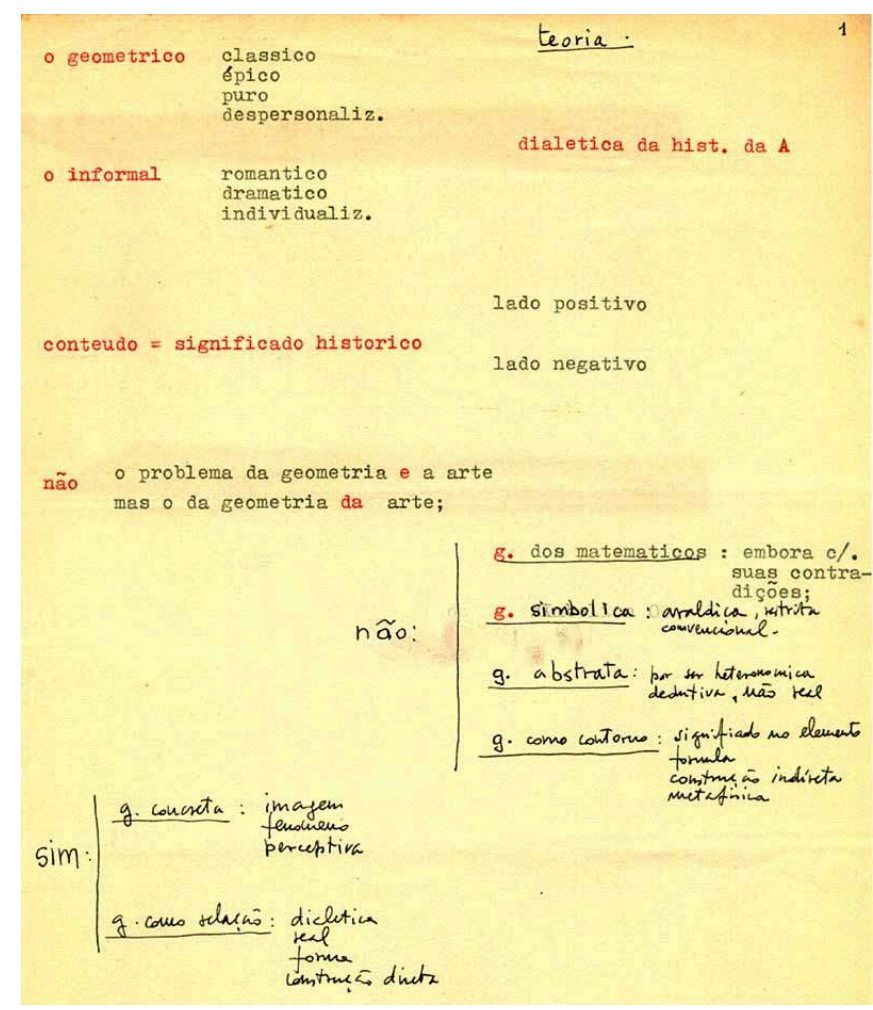

Figure 5: Waldemar Cordeiro. Diagram, c. 1953-54. Cordeiro Family Archive.

Returning in closing to the accident/incident of the archive with which I began: in the scripts for one of Cordeiro 1953-54 talks, he mentions Milliet only to dismiss him as the prototypical idealist critic in the national context followed by a parenthetical note to "read the clipping." ${ }^{2}$ So, if we imagine ourselves among the students in Cordeiro's course or perhaps the accrued public audience as the teacher and students moved through the Bienal galleries, on at least one occasion, Cordeiro pulled out his copy of his January 1953 "Ruptura" article and read from it. Did he slot his delegate card from the Continental Congress for Culture alongside the clipping before such an occasion, perhaps? While analysis of political theory and commentary on art institutions are absent from his series of remarks in 1953-54, the red card reminds us of the political commitments informing his refusal to rarefy the aesthetic tenets of Concretism and to insist on the relations of art to history and society. Not the mystified product of a divine process, Cordeiro asserted that "the new art is only a powerful instrument of knowledge that conquers reality as visibility, and objectively contributes to collective progress." 53 


\section{ENDNOTES}

1. See Waldemar Cordeiro, "Ruptura," Correio paulistano, January 11, 1953, Pensamento e Arte supplement, 3, CD-ROM Waldemar Cordeiro (São Paulo: Analívia Cordeiro and Galeria Brito Cimino, 2010), fig. 1-43.

2. Patrick Iber, "Anti-Communist Entrepreneurs and the Origins of the Cultural Cold War," in De-Centering Cold War History: Local and Global Change, eds. Jadwiga PieperMooney and Fabio Lanza (London: Routledge, 2012), 176.

3. According to Vivaldo Medeiros, Cordeiro had been a member of the Italian Communist Party and elected not to join PCB because he disagreed with the party's aesthetic program supporting social realism. Vivaldo Medeiros, "Dialética concretista: O percurso de Waldemar Cordeiro," Revista do IEB, no. 45 (September 2007): 68. On Cordeiro's engagement with the ideas of Antionio Gramsci, see Adrian Anagnost, "Internationalism, Brasilidade, and Politics: Waldemar Cordeiro and the Search for a Universal Language," Hemisphere: Visual Cultures of the Americas III (2010): 23-41.

4. Mário Pedrosa, "Da natureza afetiva da forma na obra de arte," 1949, in Mário Pedrosa, Textos escolhidos, vol. 2, Forma e percepção estética, ed. Otília Arantes (São Paulo: Edusp, 1996), 105-230. Also see Kaira Cabañas, Learning from Madness: Brazilian Modernism and Global Contemporary Art (Chicago: University of Chicago Press, 2018), 83107.

5. Waldemar Cordeiro, "Abstracionismo," Artes plásticas, no. 3 (January-February 1949): 3; Waldemar Cordeiro, "Ainda o abstracionismo," Revista dos novíssimos 1, no. 1 (January-February 1949): 27-28.

6. Cordeiro, "Ainda o abstracionismo," trans. in Mónica Amor, Theories of the Nonobject: Argentina, Brazil, Venezuela, 1944-1969 (Berkeley: University of California Press, 2016), 80.

7. To the best of my knowledge Cordeiro's earliest mention of Gestalt is: Waldemar Cordeiro, "Ia Bienal do Museu de Arte Moderna: Um consorcio das formas da visualidade estética moderna," Folha da manhã, December 22, 1951, 6.

8. Waldemar Cordeiro, Notebook Resumo e notas "Michel Seuphor, L'art abstrait: Ses origines, ses premiers meitres, maght [sic] Paris 1949," n.d., Cordeiro Family Archive.

9. Cordeiro, "Abstracionismo;" Medeiros, "Dialética concretista: O percurso de Waldemar Cordeiro," 63-86.

10. Waldemar Cordeiro, "Vaça na paisagem," n.d., in Waldemar Cordeiro: Fantasia exata, ed. Analívia Cordeiro, trans. John Norman, Marisa Shirasuna, and Izabel Burbridge (São Paulo: Itaú Cultural, 2014), 98-99, with modifications.

11. See, for example, Waldemar Cordeiro, "Salão Paulista de Arte Moderna," Folha de manhã, March 18, 1951, 9.

12. Waldemar Cordeiro, "A culpa é do abstracionismo: Bode expiatório de uma crítica que não quer criticar-devolvamos o abstracionismo à estética," Folha da manhã, December 2, 1951, 10, in Waldemar Cordeiro: Fantasia exata, 75-77.

13. Waldemar Cordeiro, "A volta do artista à vida coletiva," Folha da manhã, March 9, 1952, 11; Hideo Onaga, "Tumulto no Clube dos Artistas por causa do abstracionismo," Folha da noite, November 27, 1951, 1, 3. 
14. Cordeiro, "A volta do artista à vida coletiva."

15. Mário Pedrosa, "Exposição de artistas brasileiros," Tribuna da imprensa, April 26-27, $1952,8$.

16. The Geraldo de Barros Archive holds letters of introduction that Waldemar Cordeiro wrote to Rome-based artists Enrico Prampolini, Pietro Consagra, and Joseph Jarema on January 13, 1951 that Barros took with him to Europe.

17. Waldemar Cordeiro, "Ponto paragrafo na pintura brasileira." Folha da manhã, January 7, 1951, 5, in Waldemar Cordeiro: Fantasia exata, 142-43. The title can be translated as "Paragraph Break in Brazilian Painting."

18. Ibid., 142.

19. Ibid.

20. Waldemar Cordeiro, "Formas que não são formas: A mostra de Almir Mavignier no Museu de Arte Moderna," Folha da manhã, September 26, 1951, 6.

21. Mário Pedrosa, "Almir Mavignier," in Almir Mavignier (São Paulo: Museu de Arte Moderna de São Paulo, 1951), n.p. Also see: Mário Pedrosa, "Almir Mavignier," o estado de São Paulo, September 7, 1951, 6.

22. Gabriela Suzana Wilder states that Cordeiro had an example of Pedrosa's thesis, but to the best of my knowledge he did not comment on it in any texts. In contrast, another reviewer of Mavignier's exhibition, possibly Sérgio Milliet, noted, critically, that Mavignier's works attempted to illustrate concepts in Pedrosa's study of Gestalt theory, and a copy of Pedrosa's thesis dedicated to Milliet recently appeared at auction. Gabriela Suzana Wilder, Waldemar Cordeiro: pintor vanguardista. MA thesis, Universidade de São Paulo, 1982, 294; [Sérgio Milliet?], "Almir Mavignier," O estado de São Paulo, September 16, 1951, 8. A 1949 copy of the thesis that Pedrosa inscribed to Sérgio Milliet recently appeared at auction, likely one of a number of examples circulating among Pedrosa's circle. See http://www.budanoleiloeiro.com.br/peca.asp?ID=2751712

23. Cordeiro, "Ainda o abstracionismo."

24. Waldemar Cordeiro "Arte moderna e naturalismo: Os preconceitos artísticos da imitação e do sentido - Fundamento e superacão da teoria da duplicidade do fato artístico," Folha da manhã, December 9, 1951, 7, in Waldemar Cordeiro: Fantasia exata, 81, with modifications.

25. Ibid.

26. See, for example, Waldemar Cordeiro, "Os artistas na vida e na arte: Volpi, o pintor de parades que traduziu a visualidade popular," Folha da manhã, April 20, 1952, 7, in Waldemar Cordeiro: Fantasia exata, 150-52; Waldemar Cordeiro, "Os pintores na vida e na arte: Sacilotto, poeta da economia moderna," Folha da manhã, May 11, 1952, in Waldemar Cordeiro: Fantasia exata, 159-63.

27. Cordeiro, "Os pintores na vida e na arte: Sacilotto, poeta da economia moderna," in Waldemar Cordeiro: Fantasia exata, 161.

28. Ibid.

29. Both Heliosa Espada and Adrian Anagnost have contributed insightful scholarship on Cordeiro's relation to the Italian postwar context. Anagnost, "Internationalism, Brasilidade, and Politics;" Heloisa Espada, "Waldemar Cordeiro, the Rome Art Club and its Consequences on the Ruptura Manifesto," XIII Brazilian Studies Association Conference, Brown University, April 2, 2015. For an important analysis of the 
circulation of Bill's ideas in Argentina and Brazil, see María Amalia García, Abstract Crossings: Cultural Exchange between Argentina and Brazil (Berkeley: University of California Press, 2019).

30. Max Bill, "Schönheit aus Funktion und als Funktion," Werk 36, no. 8 (August 1949): 272-74; Max Bill, "Beleza provinda da função e beleza como função," Habitat: Revista das Artes no Brasil, no. 2 (January-March 1951): 61-64. Bill was involved in the planning of Hochschule für Gestaltung (Institute of Design, HfG) in Ulm, Germany by 1950, and he revised his text "Beauty from Function and as Function" (originally delivered as a lecture at the Swiss Werkbund in 1948) to include a mention of Ulm when it appeared in the São Paulo magazine Habitat in 1951.

31. Ibid., in Max Bill, Form, Function, Beauty = Gestalt, ed. Brett Steele, trans. Pamela Johnston (London: Architectural Association London, 2011), 32.

32. Max Bill, Form: Eine Bilanz über die Form Formentwicklung um die Mitte des XX. Jahrhunderts, A Balance Sheet... (Basel: Verlag Karl Werner, 1952), 7.

33. Cordeiro "Arte moderna e naturalismo," in Waldemar Cordeiro: Fantasia exata, 79, with modification.

34. "Notas," [1952], Geraldo de Barros Archive; "Rascunho do manifesto Ruptura," 1952, illustrated in João Bandeira, Arte concreta paulista: Documentos (São Paulo: Cosac \& Naify, 2002), 47.

35. "Rascunho do manifesto Ruptura."

36. "Manifesto Ruptura," 1952, in Inverted Utopias: Avant-Garde Art in Latin America, eds. Mari Carmen Ramírez and Héctor Olea, trans. Laura Pérez (New Haven: Yale University Press; Houston: Museum of Fine Arts, Houston, 2004), 494, with modification.

37. Waldemar Cordeiro, "Impõ-se uma revisão de valores na pintura e na escultura nacionais: A realidade presente e a critica dogmatica - do "modernismo entusiasta," Folha da manhã, February 17, 1950, 10; Waldemar Cordeiro, "A Nova alegoria: Considerações em torno da exposição de Flexor no Museu de Arte Moderna - a pintura "crime da mala," Folha da manhã, April 27, 1950, 8.

38. Sérgio Milliet, "Duas exposições," O estado de São Paulo, December 13, 1952, 6.

39. Cordeiro, "Ruptura."

40. Ibid.

41. "Manifesto Ruptura," 1952, in Inverted Utopias, 494.

42. "Manifesto Ruptura," 1952. In his 1953 article "Ruptura," Cordeiro cites the 1945 Italian translation of a portion of a posthumous 1914 publication of Fielder's writings, and the Italian publication is the likely source for the unattributed quotation in the manifesto. Konrad Fiedler, “Aphorismen," in Schiften über Kunst, vol. 2 (Munich: R. Piper \& Co., 1914); Konrad Fiedler, Aforismi sull'arte, ed. Antonio Bann, trans. Rossana Rossanda (Milan: A. Minuziano, 1945), 128.

43. Cordeiro, "Ruptura;" Fiedler, Aforismi sull'arte, 78.

44. There are several undated typed manuscripts for "palastras" in Cordeiro's papers, which I propose were delivered in late 1953 and early 1954. Two refer to works on view at the second São Paulo Bienal, which was open from December 1953 to February 1954. Waldemar Cordeiro, "Arte concreta," n.d., CD-ROM Waldemar Cordeiro, fig. 4-04; Waldemar Cordeiro, "Concretismo como arte de criação contraposta á arte de expressão," n.d., CD-ROM Waldemar Cordeiro, fig. 4-05, in Waldemar Cordeiro: Fantasia 
exata, 206-12. There is also a script for remarks dedicated exclusively to Fiedler: Waldemar Cordeiro, "O suprematismo, o néo-plasticismo e o construtivismo, do pontode-vista da pura visualidade," n.d., CD-ROM Waldemar Cordeiro, fig. 4-03, in Waldemar Cordeiro: Fantasia exata, 91-97.

45. Cordeiro's course was held between January 10-February 1, 1953 in Teresópolis and February 2-20, 1954 in São Paulo. The fifth iteration of the Curso Internacional de Férias-Pró Arte in 1953-1954 also counted Argentine artist Gyula Kosice and Brazilian poet Décio Pignatari among its teachers. Ibiapaba, "Poesia e pintura juntas na Bienal: Waldemar Cordeiro está fazendo falta no Ibirapuera," Correio paulistano, December 27, 1953, 24; “Em Teresópolis," Correio de manhã, January 6, 1954, 9; "Curso internacional de Férias em Teresópolis," Correio da manhã, February 9, 1954, 11.

46. Mário Pedrosa, Panorama da pintura moderna (Rio de Janeiro: Ministério da Educação e Saúde, 1952).

47. Adele Nelson, “Radical and Inclusive: Mário Pedrosa's Modernism," in Mário Pedrosa: Primary Documents, eds. Glória Ferreira and Paulo Herkenhoff (New York: The Museum of Modern Art; Durham, NC: Duke University Press, 2015), 35-43.

48. Cordeiro, "Concretismo como arte de criação contraposta á arte de expressão," in Waldemar Cordeiro: Fantasia exata, 2016. Also see Cordeiro, "Arte concreta."

49. Cordeiro, "Arte concreta," n.p.

50. Cordeiro, "Concretismo como arte de criação contraposta á arte de expressão," in Waldemar Cordeiro: Fantasia exata, 208.

51. Waldemar Cordeiro, "O geométrico, o informal," CD-ROM Waldemar Cordeiro, fig. 4-04c, in Waldemar Cordeiro: Fantasia exata, 100-101.

52. Cordeiro, “Concretismo como arte de criação contraposta á arte de expressão." This parenthetical statement is omitted the translation in Waldemar Cordeiro: Fantasia exata, 206-12.

53. Ibid., 212, with modification.

\section{ABSTRACTS}

By examining Waldemar Cordeiro's theory of form in little studied and well-known texts, including a newly uncovered series of talks, of the late 1940s-early 1950s, this article revises the conflation of Cordeiro's thinking, and the aims of Brazilian Concretism, with Max Bill's proposals and reveals that Cordeiro closely linked his visions of abstraction and Concrete art to social responsibility. It also sheds new light on the motivations and context for Cordeiro's deployment of Konrad Fielder's ideas and his dialogues and disagreements with Mário Pedrosa and Sérgio Milliet.

INDEX

Keywords: Brazilian art, Waldemar Cordeiro, Max Bill, Mário Pedrosa, abstraction, Concrete art 


\section{AUTHOR}

\section{ADELE NELSON}

Assistant Professor of Art History and Associate Director of the Center for Latin American Visual Studies at the University of Texas at Austin. 